\title{
Bladder perivascular epithelioid cell tumor (PEComa): A case report
}

\section{Mesane perivasküler epiteloid hücreli tümör (PEComa): olgu sunumu}

\author{
Cevdet Serkan Gokkaya ${ }^{1}$, Cüneyt Ozden ${ }^{1}$, Sahin Pasali ${ }^{1}$, Onder Bozdogan², Tolga Baglan², Bige Sayin ${ }^{3}$ \\ ${ }^{1}$ Sağlık Bilimleri Üniversitesi, Ankara Numune Eğitim ve Araştırma Hastanesi, Üroloji Kliniği, Ankara \\ ${ }^{2}$ Sağllk Bilimleri Üniversitesi, Ankara Numune Eğitim ve Araştırma Hastanesi, Patoloji, Ankara \\ ${ }^{3}$ Sağlık Bilimleri Üniversitesi, Ankara Numune Eğitim ve Araştırma Hastanesi, Radyoloji, Ankara
}

Dergiye Ulaşma Tarihi: 15.03.2020 Dergiye Kabul Tarihi: 11.04.2020 Doi: 10.5505/aot.2020.38802

\section{ÖZET}

Perivasküler epiteloid hücre tümörleri (PEComa) belirsiz malignite potansiyeli olan, çok nadir bir mezenkimal kanserdir. Mesane lokalizasyonunda primer PEComa nadir olarak görülür. PEComa'larda malignite kriterleri tümör boyutunun $5 \mathrm{~cm}$ 'den büyük olması, yüksek mitotik aktivite, nekroz, infiltrasyon ve vasküler invazyon varlı̆̆ıdır. Bu kriterlerden en az 2'sinin bulunduğu PEComa'lar malign olarak kabul edilir. Görüntüleme yöntemleri ile ayrıcı tanıya yardımcı spesifik makroskopik özellikler göstermemesi nedeni ile tanısı sadece histopatolojik inceleme ile konulabilmektedir. Mesanede tümörün büyüklüğü ve yerine göre transüretral rezeksiyon, parsiyel sistektomi veya radikal sistektomi ile cerrahi tedavi önerilir. Bu olgu sunumunda mesane lokalizasyonunda primer PEComa' 1 bir vakanın tanı ve tedavisi değerlendirildi.

Anahtar Kelimeler: Mesane, parsiyel sistektomi, perivasküler epiteloid hücre tümörleri

\begin{abstract}
Perivascular epithelioid cell tumors (PEComa) are a very rare mesenchymal cancer with unclear malignancy potential. Primary PEComa is rare in bladder localization. We have presented a case with a primary PEComa of the bladder. The criteria for malignancy in PEComas include greater than $5 \mathrm{~cm}$ tumor size, high mitotic activity, necrosis, infiltration and vascular invasion. PEComas with at least 2 of these criteria are considered malignant. The diagnosis can be made only by histopathological examination because it does not show specific macroscopic features to assist in differential diagnosis with imaging methods. Surgical treatment is recommended with transurethral resection, partial cystectomy or radical cystectomy according to the size and location of the tumor in the bladder. In this case report, the diagnosis and treatment of a case with primary PEComa in bladder localization were evaluated.
\end{abstract}

Keywords: Bladder, partial cystectomy, perivascular epiteloid cell tumors

\section{INTRODUCTION}

Perivascular epithelioid cell tumors (PEComa) are a very rare mesenchymal cancer with unclear malignancy potential (1). Angiomyolipoma, clear cell sugar tumor of the lung and lymphangioleyomyomatosis are part of the PEComa family $(2,3)$. PEComa has been reported in various localizations including uterus, falciform ligament, vulva and prostate (3). Primary PEComa is rarely seen in bladder localization. The criteria for malignancy in PEComas include greater than $5 \mathrm{~cm}$ tumor size, high mitotic activity, necrosis, infiltration and vascular invasion. PEComas with at least 2 of these criteria are considered malignant (2). In this case report, the diagnosis and treatment of a case with primary PEComa in bladder localization were evaluated.

\section{CASE REPORT}

A 37-year-old male patient was admitted to our clinic in July 2015 with the complaint of painless hematuria that persisted for the last 2 months. The patient's medical history and family history were unremarkable. The patient had a smoking habit. Physical examination was normal. Chest X-ray, hemogram values, serum biochemistry and 
urine culture were normal. Abdominopelvic computed tomography (CT) revealed a $66 \times 75$ $\mathrm{mm}$ homogeneous, highly dense mass in the right anterolateral wall of the bladder which has necrosis areas at the centre. Neovascularization was present around the mass and the entire bladder (Figure 1). In cystoscopy performed under general anesthesia, the bladder mucosa was normal and there was an impression of $3 \mathrm{~cm}$ mass at the dome near the right side wall which originated from outside the bladder. This mass was not transurethrally resected because it was known to be highly vascularized on abdominopelvic CT. Percutaneous biopsy was planned. Trucut biopsy from the mass performed by interventional radiology. Pathological examination of the smears was pointing a lesion which is a member of perivascular epithelioid cell tumors (PEComa) group, especially angiyomyolipoma. With these findings, partial cystectomy was performed in the patient who was thought to have primary PEComa localized in the bladder. The patient was discharged on the 7th postoperative day. The macroscopic examination of the surgical specimen revealed a $7 \times 6,5 \times 6 \mathrm{~cm}$ sized, encapsulated, smooth surface, occasional hemorrhagic and a medium hardness lesion. The pathological examination of the specimen was consistent with perivascular epithelioid cell tumor (PEComa) and was reported to contain malignancy potential because of the presence of a lesion greater than $5 \mathrm{~cm}$, cellularity, pleomorphism, and giant cells (Figure 2). The patient followed up with local cystoscopy and abdominopelvic CT. There is no local and systemic recurrence at the postoperative 36th month.

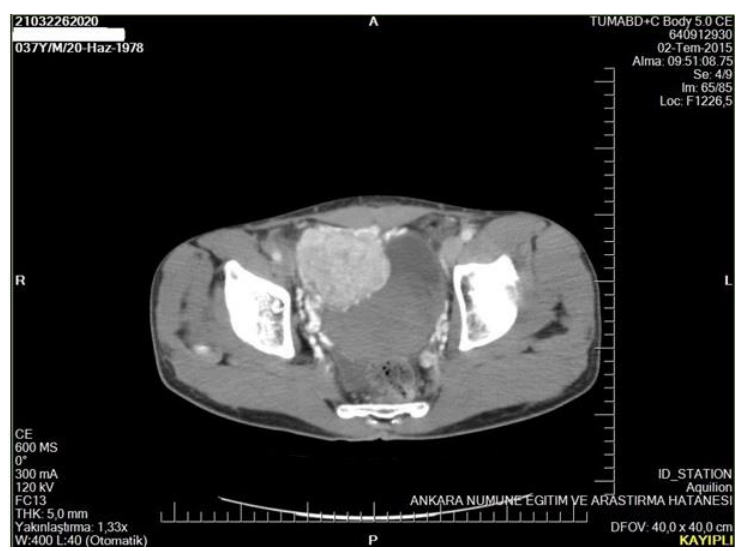

Figure 1: Mass on the right anterolateral wall of the bladder in computed tomography

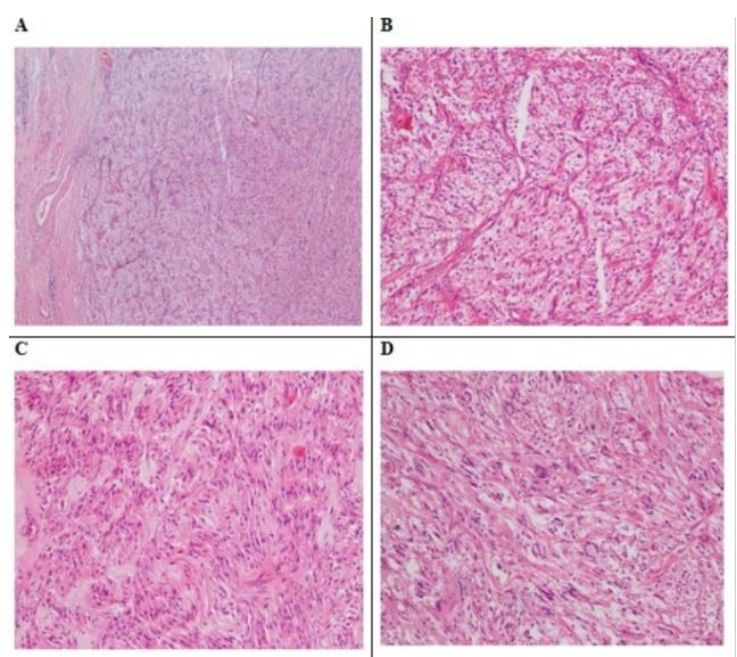

Figure 2: Histopathologic examination revealed neoplasia of well-defined, clear and eosinophilic epithelioid cells (A, B), Spindle cells (C) and giant cells are seen in some areas (D). H\&E, Original magnification; A X40, B, C, D X100

\section{DISCUSSION}

Perivascular epithelioid cell tumors (PEComa) are a very rare mesenchymal cancer with unclear malignancy potential. In 1992, Bonetti and colleagues described the perivascular epithelioid cells in the angiomyolipomas of the kidney and liver and in the clear cell sugar tumors of the lung as PEC. In 1996, Zamboni et al. suggested the use of the term PEComa for mesenchymal neoplasms consisting of perivascular epithelioid cells (4). The term PEComa is an inclusive term, including angiomyolipoma, a clear-cell "sugar" tumor of the lung and extrapulmonary regions, lymphangioleyomyomatosis, a clear cell myomelanocytic tumor of the falsiform ligament / ligamentum teres, and rare transparent cell tumors of other anatomical regions (5).

The diagnosis can be made only by histopathological examination because it does not show specific macroscopic features to assist in differential diagnosis with imaging methods (6). Perivascular epithelioid cells are typically cells with epithelioid appearance in the perivascular localization, with a centrally located, round-oval nucleus, an unclear nucleolus and transparent-granulated cytoplasm (5). PEComas are mesenchymal tumors showing melanocytic and smooth muscle cell characteristics. This pathological finding has been demonstrated by the detection of immunohistochemical positivity of melanocytic 
markers (SMA, MSA, heartin, caldesmon) in addition to smooth muscle cell markers (HMB45, Melan A tyrosinase, microphthalmia transcription factor) (7).

PEComas can be detected in all parts of the body, although uterus is the most common organ (4). In the genitourinary system bladder is second most common organ after kidney. In the English literature, 19 cases of PEComa which originated from the bladder have been reported so far $(5,6,8)$. They are observed equally in both sexes. The age of diagnosis is between 16 and 64 years. The mean age at diagnosis was 35.8 years. The sizes of the masses identified so far vary between $1.5 \mathrm{~cm}$ and $9.2 \mathrm{~cm}$ (4). Except for the case described by Russel et al. in 2014, PEComas originating from the bladder were observed solitary $(5,8)$.

The most common symptom is hematuria in PEComa cases originated from the bladder described so far as our case. Other than hematuria, pelvic pain, abdominal discomfort, frequent urination, dysuria, urethral pain are the other symptoms observed at the time of diagnosis (9). In 2006, Parfitt et al. diagnosed a PEComa with enterovesical fistula (1).

In 2005 Folpe et al. defined the malignancy criterias for non-angiomyolipoma, soft tissue and gynecological PEComas. According to this study, which 26 cases were examined, PEComas were divided into 3 groups as benign, indefinite malignant potential, and malignant. PEComas with a low cellularity, less than $5 \mathrm{~cm}$, low nuclear grade, mitotic rate less than $1 / 50 \mathrm{hpf}$, non-infiltrating, without vascular invasion and necrosis were classified as benign. PEComas have at least 2 of the malignant criterias which are greater than $5 \mathrm{~cm}$, infiltrative growth pattern, high mitosis, pleomorphism, necrosis or vascular invasion were classified as malignant. PEComas carrying only one of these features were classified as indefinite malignant potential (2). Our case was thought to be malignant because of the fact that the mass was $7 \mathrm{~cm}$, the proliferation index was 5\%, and it included pleomorphism. According to this classification, at least 7 cases presented so far should be classified as malignant. However, only 3 of them have an aggressive behavior pattern. Only one of the cases died 12 months after diagnosis because of metastatic disease. Therefore, the behavior pattern of PEComas arising from the bladder cannot be clearly predicted $(5,6)$.
In the current literature, the optimal treatment of PEComas originating from the bladder is unknown. According to the cases described so far, 6 were treated with TUR-MT (transurethral bladder resection), 3 were treated by partial cystectomy after TUR-MT, 8 were treated by partial cystectomy and 2 were treated by radical cystectomy after TUR-MT $(5,8)$. The patient was diagnosed with enterovesical fistula by Parfitt at al. in 2006 treated with IFN- $\alpha$ in addition to partial cystectomy and partial bowel resection. No recurrence was reported in the patient with follow-up of 48 months (1). Williamson et al. described a case with TFE3 gene mutation in 2013 and treated with radical cystectomy after TUR-MT becouse of recurrence at 6th month. Although the patient received palliative chemotherapy for sarcoma, he died in the 12th month after the diagnosis. Palleschi et al. diagnosed a primary bladder PECome with multiple bone metastases in 2014. The patient was diagnosed with TUR-MT and chemotherapy was planned with anthracycline which is the first line treatment in soft tissue tumors, due to skeletal metastasis. However he had systolic and diastolic cardiac dysfunction so he was treated with gemcitabine. It was reported an improvement in bone metastases 6 months after the beginning of treatment and there was no new lesion (6).

Because of most cases have a benign character, the primary excision of the mass is usually curative. Our case was treated with partial cystectomy and no recurrence was observed in 36 months follow-up. Although treatment modalities such as chemotherapy, radiotherapy and immunotherapy are used in local advanced and metastatic diseases in PEComas, these treatments are observed as case reports rather than standardized and validated treatment protocols (8).

PEComas have been associated with autosomal dominant inherited genetic diseases with loss of TSC1 (tuberous sclerosis complex 1) and TSC2 genes which are thought to play a role in the mTOR (mammalian Target of rapamycin) pathway. Therefore, the use of mTOR inhibitors in the medical treatment of PEComas has been tried and successful results have been obtained. A case of complete remission with everolimus was reported in a patient with retroperitoneal PEComa. However, this association found in other PEComas has not 
been shown in any of the primary bladder PEComas so far $(6,7)$.

\section{CONCLUSION}

\section{REFERENCES}

1. 1. Parfitt JR, Bella AJ, Wehrli BM, Izawa JI. Primary PEComa of the bladder treated with primary excision and adjuvant interferon-alpha immunotherapy: a case report. BMC Urol 2006;22(6):20.

2. 2. Tarplin S, Osterberg EC, Robinson BD, Herman MP, Rosoff JS. Perivascular epithelioid cell tumour of the bladder. BMJ Case Rep 2014;14: 2014. doi: 10.1136/bcr-2014-205500.

3. 3. Shringarpure SS, Thachil JV, Maya M. PEComa of the urinary bladder. Saudi J Kidney Dis Transpl 2012;23(5):1032-4. doi: 10.4103/1319-2442.100943.

4. 4. Sarti A, Rubilotta E, Balzarro M, Cerruto MA, Brunelli M, Artibani W. Bladder perivascular epithelioid cell tumor (PEComa): a case report and literature review. Urologia 2015;82(2):120-3. doi: 10.5301/urologia.5000045.

5. 5. Martignoni G, Pea M, Zampini C, Brunelli M, Segala D, Zamboni G, et al. PEComas of the kidney and of the genitourinary tract.SeminDiagnPathol 2015;32(2):140-59.

doi: 10.1053/j.semdp.2015.02.006.
Primary PEComas of bladder is a rare pathology with unclear malignancy potential. Surgical treatment is recommended with transurethral resection, partial cystectomy or radical cystectomy according to the size and location of the tumor in the bladder. Close follow-up of cystoscopy and imaging methods should be performed in cases with have malignancy potential.

6. 6. Palleschi G, Pastore AL, Evangelista S, Silvestri L, Rossi L, Di Cristofano C, et al. Bone metastases from bladder perivascular epithelioid cell tumor - an unusual localization of a rare tumor: a case report. J Med Case Rep 2014;8: 227. doi: 10.1186/1752-19478-227.

7. 7. AbouGhaida R, Nasr R, Shahait M, Khairallah A. Bladder perivascular epithelioid cell tumours. BMJ Case Rep 2013;2013:200153. doi:10.1136/bcr-2013200153.

8. 8. Creti S, Romagnoli D, Severini E, Baldoni C, Bondi A, Di Campli A, et al. Primary Perivascular Epithelioid Cell Tumor (PEComa) of the Bladder: A Case Report With 2-Years of Follow-Up and Review of Current Literature. ClinGenitourin Cancer 2017;15(1):e79-e81. doi: 10.1016/j.clgc.2016.08.010.

9. 9. Yin L, Bu H, Chen M, Yu J, Zhuang H, Chen J, et al. Perivascular epithelioid cell neoplasm of the urinary bladder in an adolescent: a case report and review of the literature. DiagnPathol 2012;7:183. doi: 10.1186/1746-1596-7-183. 